US Army Corps

of Engineers

Waterways Experiment

Station

\title{
Wave Refraction at Redondo Beach, California (Comparison of Field Measurements with Models)
}

by Joon P. Rhee, William D. Corson

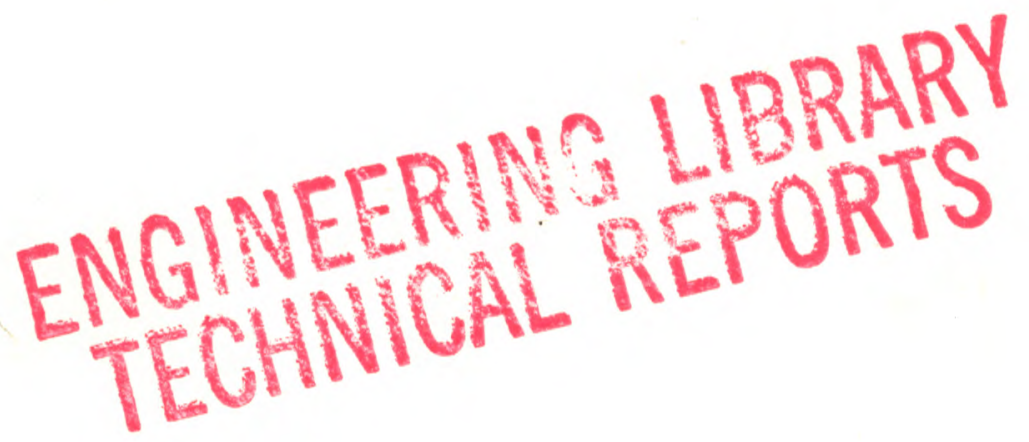

Approved For Public Release; Distribution Is Unlimited

Prepared for Headquarters, U.S. Army Corps of Engineers

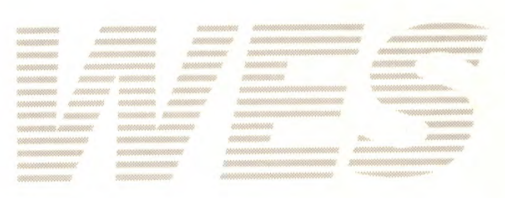

